\title{
A INTERDISCIPLINARIDADE É DESEJÁVEL, MAS O MODELO NÃO PODE SER IMPOSTO
}

A interdisciplinaridade no campo das ciências é um conceito amplo e complexo de construção do conhecimento, que deve ultrapassar a disciplina isolada. Essa concepção deve partir de um modelo de ensino que privilegie e articule as ciências Matemática, Biologia, Química, Física, História etc, em um ambiente amplo em que os fenômenos sejam observados, analisados e entendidos como fatos conectados.

Por força de resolução, as nossas escolas têm autonomia, desde 1998, para organizar os conteúdos das suas disciplinas e definir as metodologias para sua aplicação, quando as Diretrizes Curriculares Nacionais para o Ensino Médio, baseadas no parecer CEB/CNB n ${ }^{-}$ 15/98, foram instituídas pela Resolução $n^{\circ}$ 4/98. Essa resolução determinou que os currículos fossem organizados em três áreas de conhecimento sem abandonar as disciplinas do currículo escolar, torná-las superficiais e/ou criar a figura do professor "superespecializado".

Os fenômenos científicos são, por natureza, complexos e sem recortes definidos sendo, portanto, importante que sejam estudados de forma conjunta. Para se encarar esse desafio os temas podem ser tratados por diferentes disciplinas, mas com um olhar multidisciplinar. Nesse modelo não ocorrem quebras entre as disciplinas e se formam os eixos integradores de ensino.

Recentemente foi noticiado na grande imprensa que o MEC iniciou as discussões para a reforma do currículo do ensino médio no País. Ele pretende até o início de 2013 enviar ao Conselho Nacional de Educação (CNE) proposta com a redução do número de disciplinas em quatro eixos temáticos. As disciplinas de Física, Química e Biologia seriam integradas em uma única disciplina chamada de Ciências Naturais.

Da forma que está sendo conduzido esse processo de fusão de disciplinas em áreas interdisciplinares, sem estar baseado em sólidos estudos pedagógicos e de viabilidade, é um retrocesso histórico. Não há dúvidas que essa medida, que vai alterar radicalmente a carreira de milhões de alunos e professores, deve ser bem refletida e discutida com a sociedade.

Esperamos que o Ministério da Educação tenha sensibilidade para entender que uma modificação tão drástica no ensino médio precisa de uma ampla discussão com a sociedade e os educadores, antes de ser aprovada e posta em prática. A Sociedade Brasileira de Química (SBQ) acredita que interdisciplinaridade é desejável, mas o modelo não pode ser imposto sem amplo debate.

Certamente, os atuais avanços científicos e tecnológicos alcançados são oriundos de trabalhos interdisciplinares, tendo as ciências Física, Química e Biológica como áreas autônomas e com formação de profissionais em cada área. Os alunos do ensino superior que ingressam nessas carreiras, e em outras também, têm forte noção da interdisciplinaridade dessas áreas e têm se aproveitado para trabalhar livremente suas iniciações científicas em diversos laboratórios sem se importarem com a carreira optada inicialmente. Essa interdisciplinaridade é natural e desejável. Porém, é quase unanimidade que os alunos do ensino médio precisam ser mais bem preparados em
Matemática, Física, Química e Biologia, para que possam se tornar melhores profissionais.

Para que isso ocorra é preciso que as escolas tenham salas confortáveis, acesso à Internet, laboratórios adequados em que se possam dar aulas experimentais planejadas e interdisciplinares, experimentos bem desenhados, com professores bem remunerados e com dedicação exclusiva.

A SBQ já manifestou através de carta ao Ministro da Educação sua preocupação com a proposta de fusão das disciplinas Química, Física e Biologia no nível médio de ensino, pelas razões elencadas abaixo:

1. até o momento não consta que exista qualquer estudo profundo sobre este tema que justifique tal mudança radical, e não é consenso na comunidade que lida com educação de que a fragmentação do currículo prejudica a aprendizagem;

2. a redução do número de disciplinas, ao invés de integrar seus conteúdos, vai diluí-los e torná-los superficiais e generalistas;

3. a carência de licenciados nas áreas técnicas de Química, Física e Biologia no nível médio de ensino não pode ser a força motriz oculta dessa proposta;

4. que profissionais as universidade formarão para atender à disciplina de Ciências Naturais?

5. O argumento de que a rede estadual de Pernambuco já adota modelo semelhante ao pretendido pelo MEC não justifica a cópia desse modelo para o país, sem se ter resultados conclusivos e positivos, que demonstrem que esta fórmula é muito melhor que a existente;

6. a cooptação de escolas para aderirem ao projeto do MEC, dos quatro grandes eixos norteadores do Enem, com repasses adicionais de recursos é injusta e quebra os princípios da isonomia do ensino.

O pior cenário é o MEC impor aos professores de Biologia, de Química ou de Física que elaborem e revisem itens de qualquer uma destas disciplinas para a prova do Enem, ou seja, impondo a disciplina de Ciências Naturais sem que tenha sido aprovada.

No momento, a SBQ ainda não se posicionou quanto à iniciativa do MEC, mas solicita que antes de se implantar esse novo modelo sejam apresentados os estudos realizados para embasar tal mudança radical. Além disso, a Sociedade precisa saber qual a estratégia, a metodologia que será utilizada, os prazos e as metas que se pretendem alcançar.

$\mathrm{Na}$ carta ao Sr. Ministro escrevemos que “...não basta uma boa ideia, é preciso ter uma boa metodologia que suporte a implementação e o sucesso da ideia", agora enfatizamos - a interdisciplinaridade é desejável, mas o modelo não pode ser imposto para a sociedade sem discussão prévia. 